\title{
Isolation and identification of secondary metabolite acetone extract Aaptos sp. and its antioxidant properties and acute toxicity
}

\author{
Adryan Fristiohady ${ }^{1}$, Baru Sadarun², Wahyuni Wahyuni ${ }^{1}$, Muhammad Hajrul Malaka ${ }^{1}$, Fandi Ahmad ${ }^{1}$, Fadhliyah Malik ${ }^{1}$, \\ La Ode Muhammad Julian Purnama ${ }^{1}$, Idin Sahidin ${ }^{1 *}$
}

${ }^{1}$ Faculty of Pharmacy, Halu Oleo University, Kendari, Indonesia.

${ }^{2}$ Faculty of Fisheries and Marine Science, Halu Oleo University, Kendari, Indonesia.

\begin{tabular}{l}
\hline ARTICLE INFO \\
\hline Received on: 05/06/2019 \\
Accepted on: $27 / 02 / 2020$ \\
Available online: $05 / 06 / 2020$
\end{tabular}

\section{Key words:}

Isolation; Aaptos sp., antioxidant activity, toxicity acute.

\begin{abstract}
Aaptos sp. can be developed and utilized as a new antioxidant source. This study aims to investigate the antioxidant activity and its acute toxicity of acetone ASE stands for Aaptos sp. Extract and its isolates. Aaptos sp. was extracted by acetone, followed by fractionating with vacuum liquid chromatography, liquid-liquid partition, and radial chromatography. Each step was intervened with thin-layer chromatography. Isolates identified by comparing their physical properties and ${ }^{1} \mathrm{H}$ and ${ }^{13} \mathrm{C}$ NMR stands for Nuclear Magnetic Resonance spectrum with literature data. Antioxidant activity assayed qualitatively and quantitatively, and the acute toxicity assayed with brine shrimp lethality test. Isolates of ASE (44 g) obtained were AS1 $(50 \mathrm{mg})$, AS2 $(23 \mathrm{mg})$, AS3 (8.3 mg), and AS4 (22 mg). AS1 is identified as cholestanol. Antioxidant activity assayed qualitatively showed that ASE, AS1, AS2, and AS5 were showing as antioxidant activity, only ASE had $\mathrm{IC}_{50}$ values $16.10 \mu \mathrm{g} / \mathrm{ml} . \mathrm{LC}_{50}$ of ASE, AS1, AS2, and AS5 were 1,041.5 $\mu \mathrm{g} / \mathrm{ml} ; 1,488.33 \mu \mathrm{g} / \mathrm{ml} ; 681,87 \mu \mathrm{g} / \mathrm{ml}$; and $783,21 \mu \mathrm{g} / \mathrm{ml}$, respectively. In conclusion, there are four isolates from the ASE although only cholestanol (AS1) successfully identified. ASE, AS1, AS2, and AS5 have antioxidant activity but only $\mathrm{IC}_{50}$ of ASE was measured and they are regarded as safe with $\mathrm{LC}_{50}>1,000$ for ASE and $\mathrm{LC}_{50}>200$ for its isolates.
\end{abstract}

\section{INTRODUCTION}

The free radicals are the presence of an unpaired electron that is unstable and highly reactive. The free radical formation is a side product of metabolism or from external sources. Pollution, UV stands for ultraviolet radiation, smoke, fast-food, high-fat meal, and addictive substance are external sources of the formation of free radicals in the body. Normally, the body will produce endogenous antioxidant, such as glutathione, alpha-lipoic acid, coenzyme Q, ferritin, uric acid, bilirubin, superoxide dismutase, catalase, and glutathione peroxidase as the homeostatic process of free radical formation, thereby they will be balanced. Exposures of these factors unwittingly hasten up the formation of free radical

\section{${ }^{*}$ Corresponding Author}

Idin Sahidin, Faculty of Pharmacy, Halu Oleo University, Kendari, Indonesia.E-mail: sahidin02@uho.ac.id rate. The endogenous antioxidant defense will not be enough if the formations of free radicals are excessive (Lobo et al., 2010).

Stress oxidative must be avoided because it can damage the cell components, including proteins, DNA, and lipid membranes, thus resulting in necrosis. It leads to degenerative deterioration and development of diseases, such as cancer, cardiovascular disease and diabetes mellitus type II, cataract, arthritis, autoimmune disease, and neurodegenerative diseases (Kabel, 2014; Wojick et al., 2010). The human body does not synthesize excessive amounts of the endogenous antioxidant, thus exogenous antioxidants are needed (Dharini et al., 2010).

The discovery of exogenous antioxidants is a choice for the development and utilization of natural resources. Indonesia is one of the largest archipelago countries in the world that has abundant natural resources. They can be developed and utilized in the discovery of novel medicines. Marine sponges including Aaptos sp. are one of the biota that can be used for drug discovery because many bioactive substances can be found (Kudo et al., 2014; Uli et al., 2017). 
The previous study showed that sponge Aaptos sp. exhibits activity as an anticancer, antibacterial, and antidepressant (Shaari et al., 2009). Sponge Aaptos sp. contains secondary metabolites, such as aaptamine, isoaaptamine, aaptoline, and dimethylaaptamine (Aoki et al., 2006; Quiao and Uy, 2013; Tsukamoto et al., 2010; Kudo et al., 2014).

Despite the discovery of a novel drug is essential, knowledge of potential toxic effect is equally important. The toxicity test is important to conduct as well as an initial parameter of drug safety prior tested to human. This is because each substance has potential toxicity depending on the dose in the body (Andreanus et al., 2002). Therefore, this study aims to investigate secondary metabolites of Sponge Aaptos sp. by isolating the isolates to discovering its antioxidant property and proving its acute toxicity thus can support the treatment of medication accurately in the future.

\section{MATERIALS AND METHODS}

\section{Sponge collection}

Sponge sample (Aaptos sp.) was collected from Bintang Samudra Marine Edu-Park, Soropia Sub District, Konawe District, South East Sulawesi. Sponge sample was collected from the reef slope $\left(70^{\circ}\right)$ with depth $10 \mathrm{~m}$ above sea level by SCUBA (Self Contained Underwater Breathing Apparatus) diving. The sample was determined by staff of Faculty of Fisheries and Marine Science, Universitas Halu Oleo (NO. 537/un29.20/KAPUSLIT/2019). The sample collected then put in the icebox.

\section{Extraction}

Sponge sample (Aaptos sp.) was washed and cleaned from impurities, then chopped into pieces. The sample was macerated with acetone for $3 \times 24$ hours. Filtrate and reside were separated and replaced the solvent. Collected filtrated was then concentrated by using vacuum rotary evaporator $\left(B u c h i^{\circledR}\right)$ and yielded amount $44 \mathrm{~g}$ concentrated extract.

\section{Isolation, purification, and identification of isolates}

Fractionation and Isolation of phytochemicals of acetone extract of Aaptos sp. were using vacuum liquid chromatography (VLC), liquid-liquid partition, and radial chromatography (RC). Every step of fractionation and isolation was intervened by thinlayer chromatography (TLC) Si-Gel $\mathrm{F}_{254}\left(\right.$ Merck $\left.^{\circledR}\right)$ and observed under UV light (UVG-58) 245 and $366 \mathrm{~nm}$ and sprayed with cerium sulfate $(\mathrm{CeSO} 4)\left(\right.$ Merck $\left.^{\mathbb{R}}\right)$.

Isolates obtained was identified by its physical properties, TLC profile, and ${ }^{1} \mathrm{H}$, and ${ }^{13} \mathrm{C}$-NMR spectrum $\left(\right.$ Agilent $\left.{ }^{\circledR}\right)$. Isolates were then elucidated and compared with literature data.

\section{Measurement of antioxidant activity of isolates}

Antioxidant activity was assayed qualitatively and quantitatively. Qualitatively, antioxidant activity was assayed with the dot blot assay method. The various concentrations of extract and isolates, as follows:

Positive Control (Ascorbic Acid (AA)):5,000 $\mu \mathrm{g} / \mathrm{ml}$; $2,500 \mu \mathrm{g} / \mathrm{ml} ; 1,250 \mu \mathrm{g} / \mathrm{ml}$; and $625 \mu \mathrm{g} / \mathrm{ml}$

Acetone extract of

Aaptos sp. (ASE)

Isolate AS1
Isolate AS2

Isolate AS5 : $25 \mu \mathrm{g} ; 12.5 \mu \mathrm{g} ; 6.25 \mu \mathrm{g}$; and $3.125 \mu \mathrm{g}$ : $25 \mu \mathrm{g} ; 12.5 \mu \mathrm{g} ; 6.25 \mu \mathrm{g}$; and $3.125 \mu \mathrm{g}$

The sample then spotted and run on the TLC plate and dipped into DPPH stands for 2,2-diphenyl-1-picrylhydrazil. The plate observed on visible light and UV $366 \mathrm{~nm}$.

Quantitatively, antioxidant activity was measured under spectrophotometer (Genesys-20) with modified DPPH assay. The various concentrations of extract and isolates were 200; 100; 50: $25: 12.5: 6.25: 3.125$; and $1.5,625 \mu \mathrm{g} / \mathrm{ml}$, respectively, to determine the $\mathrm{IC}_{50}$ values.

Data recorded were calculated by as follows:

Percentage of scavenging radical $=\left(\right.$ abs. of blank $\left.-\frac{\text { abs.of sample }}{\text { abs.of blank }}\right) \times 100$

Statistical analysis was done by using $\operatorname{SPSS}^{\circledR}$ (Statistical Product and Service Solution) 21.0 for determining the significant difference between isolates and positive control $(p<0.05)$. $\mathrm{IC}_{50}$ values were determined by GraphPad Prism 5 (GraphPad Software $^{\circledR}$, La Jolla, California, USA).

\section{Acute toxicity test}

Acute toxicity test was done by brine shrimp lethality test.

Percentage of lethality $=\frac{(\text { total larvae }- \text { number of live larvae })}{\text { total larvae }} \times 100$

The various concentrations used were 2,000 ppm$15.625 \mathrm{ppm}$ for the sample and positive control $(\mathrm{K}+)$ and $12.5 \%$ $0.03902626 \%$ for the negative control (K-). Samples used were acetone extract of Aaptos sp. (ASE), compound AS1, compound AS2, and compound AS5. The positive control used was potassium dichromate and the negative control used was DMSO.

$\mathrm{LC}_{50}$ of isolates was obtained from the Probit analysis among the variation dose of extract and isolates and the number of death larvae of Artemia salina by using Minitab ${ }^{\circledR}$ ver 17.1.2.

\section{RESULTS AND DISCUSSION}

\section{Isolation and purification of isolates}

Acetone extract of Aaptos sp. (44 g, 10\%) was fractionated by VLC with n-hexane:ethyl acetate $(10: 0,9: 1,8: 2$, $7: 3,5: 5$, and 3:7), ethyl acetate:methanol (10:0), and methanol $100 \%$ to increase the polarity. Fractions $1-5$ and fraction washedmethanol were obtained from eluates that showed similar TLC profiles. Faction 2 was purified with RC and obtains the compound AS1 (50 mg) with eluent n-hexane: ethyl acetate (9:1). Fraction washed-methanol was partitioned with n:hexane:ethyl acetate $(1: 1)$ and thereafter, the partition was combined after TLC profile that showed similar eluates and continued with RC with eluent n-hexane:dichloromethane:ethyl acetate (1:8:1) obtained Fraction A-E. Purification of fraction B with RC with eluent $n$-hexane:dichloromethane:ethyl acetate $(1: 8: 1)$ obtained three different fractions (fraction A1, A2, and A3), followed purification fraction A2 with RC with eluent n-hexane:ethyl acetate:dichloromethane (1:7:2) provided compound AS2 (23 $\mathbf{m g})$ and AS3 (8.3 $\mathbf{~ m g})$. Fraction D was purified with RC with eluent ethyl acetate:dichloromethane:methanol (4:5:1) provided compound AS4 (22 mg). 


\section{Identification with ${ }^{1} \mathrm{H}$, and ${ }^{13} \mathrm{C}$-NMR spectrum}

\section{Compound AS1}

Compound AS1 was white crystal. AS1 was not showing spot under UV $254 \mathrm{~nm}$ and $366 \mathrm{~nm}$ although showed spot after sprayed with cerium sulfate $\left(\mathrm{CeCl}_{3}\right)$ reagent. Thus, the steroid compound suspected. The ${ }^{1} \mathrm{H}$ NMR AS1 compound had a similar proton signal of steroid, which was characterized by overlapping proton signals at $\delta 0-3 \mathrm{ppm}$. The ${ }^{1} \mathrm{H}$ NMR signal of compound AS1 was characterized with six distinctive peaks of five high-intensity methyl group at $\delta 0.63(\mathrm{H}-18), 0.78(\mathrm{H}-$ 19), 0.084 (H-26), $0.89(\mathrm{H}-27)$, and $0.96(\mathrm{H}-21) \mathrm{ppm}$ and proton signal at $\delta 3.57 \mathrm{ppm}(\mathrm{H}-3)$ showed proton signal hydroxylatedmethine, hence hydroxide bond/ hydroxyl group $(-\mathrm{OH})$ suspected in structure (Table 1).

The ${ }^{13} \mathrm{C}$ NMR signal was not presented above 90 ppm describing the steroid-AS1 compound, were not having a carbon-carbon double bond. The ${ }^{13} \mathrm{C}$ NMR signal compound AS1 presented 6 methyl carbon $\left(\mathrm{CH}_{3}\right)$ signal observed at $\delta 12.2(\mathrm{C}$ 18), 12.4 (C-18), 18.8 (C-21), 22.7 (C-26), and 22.9 (C-27) ppm in AS1 structure. Total 27 carbons of the steroid-AS1 compound with 12 carbon methylene $\left(\mathrm{CH}_{2}\right) ; 8$ carbon methine $(\mathrm{CH})$; and 12 carbon quartern $(\mathrm{Cq})$. Carbon methine signal presented at $\delta$

Table 1. Comparasion of ${ }^{1} \mathrm{H}$ and ${ }^{13} \mathrm{C}$ NMR of compound $\mathrm{AS} 1$ (ppm, measured under $100 \mathrm{MHz}\left({ }^{13} \mathrm{C}\right)$ and $400 \mathrm{MHz}\left({ }^{1} \mathrm{H}\right)$ in $\mathrm{CDCl}_{3}, \delta \mathrm{TMS}=0$.

\begin{tabular}{|c|c|c|c|c|c|}
\hline \multicolumn{3}{|c|}{ Compound AS1 } & \multicolumn{3}{|c|}{ Pembanding (Mohamad, dkk., 2009) } \\
\hline C\# & $\boldsymbol{\delta}_{\mathrm{C}}$ & $\delta_{\mathrm{H}}(\Sigma \mathbf{H}, \boldsymbol{m}, \mathbf{J} \mathbf{H z})$ & C\# & $\boldsymbol{\delta}_{\mathrm{C}}$ & $\delta_{\mathrm{H}}$ \\
\hline 1 & 37,1 & - & 1 & 37,2 & - \\
\hline 2 & 35,5 & - & 2 & 35,7 & - \\
\hline 3 & 71,5 & $3,57(1 \mathrm{H}, \mathrm{m}, 4)$ & 3 & 71,6 & $3,59 \mathrm{~m}$ \\
\hline 4 & 44,9 & - & 4 & 45,1 & - \\
\hline 5 & 54,4 & - & 5 & 54,6 & - \\
\hline 6 & 21,3 & - & 6 & 21,5 & - \\
\hline 7 & 24,3 & - & 7 & 24,4 & - \\
\hline 8 & 31,6 & - & 8 & 31,8 & - \\
\hline 9 & 56,4 & - & 9 & 56,5 & - \\
\hline 10 & 32,2 & - & 10 & 32,3 & - \\
\hline 11 & 19,7 & - & 11 & 19,8 & - \\
\hline 12 & 40,1 & - & 12 & 40,3 & - \\
\hline 13 & 36,3 & - & 13 & 36,4 & - \\
\hline 14 & 42,7 & - & 14 & 42,8 & - \\
\hline 15 & 23,9 & - & 15 & 24,1 & - \\
\hline 16 & 28,4 & - & 16 & 28,5 & - \\
\hline 17 & 56,6 & - & 17 & 56,7 & - \\
\hline 18 & 12,2 & $0,63(3 \mathrm{H}, \mathrm{s})$ & 18 & 12,3 & $0,65 \mathrm{~s}$ \\
\hline 19 & 12,4 & $0,78(3 \mathrm{H}, \mathrm{s})$ & 19 & 12,5 & $0,81 \mathrm{~s}$ \\
\hline 20 & 38,3 & - & 20 & 38,4 & - \\
\hline 21 & 18,8 & $0,96(3 \mathrm{H}, \mathrm{d}, 12)$ & 21 & 18,9 & $0,9 \mathrm{~d}$ \\
\hline 22 & 35,9 & - & 22 & 36,0 & - \\
\hline 23 & 28,1 & - & 23 & 28,2 & - \\
\hline 24 & 39,6 & - & 24 & 39,7 & - \\
\hline 25 & 28,8 & - & 25 & 29,0 & - \\
\hline 26 & 22,7 & $0,89(3 \mathrm{H}, \mathrm{t}, 8)$ & 26 & 22,7 & $0,87 \mathrm{~d}$ \\
\hline 27 & 22,9 & $0,84(3 \mathrm{H}, \mathrm{d}, 8)$ & 27 & 23,0 & $0,86 \mathrm{~d}$ \\
\hline
\end{tabular}

71.5ppm (C-3) which supposed to present at 35-50 ppm. Thus, concluded that the carbon methine is hydroxylated (Pavia et al., 2009). The hydroxylated-carbon methine was correlated with methine proton signal at ${ }^{1} \mathrm{H}$ NMR as well as bonded at methine at ${ }^{1} \mathrm{H}$ NMR (Figure 1). Based on the signal presented at ${ }^{1} \mathrm{H}$ NMR and ${ }^{13} \mathrm{C}$ NMR compared with literature (Mohamad et al., 2009), compound AS1 predicted as cholestanol (Figure 2).

\section{Compound AS2}

Compound AS2 was yellowish mass. AS2 was showing as a yellowish spot only visible under UV $366 \mathrm{~nm}$. Compound AS2 is still under further identification hence the structure cannot be displayed in this paper. The initial identification of compound AS2 was possibly indicating proton signals of methyl, methylene, methine, methoxy, C-C double bond, and aromatic group. Signal proton of compound AS2 presented in Table 2 and Figure 3.

\section{Compound AS3}

Compound AS3 was yellowish mass. The spot was only visible under UV $254 \mathrm{~nm}$ as a yellowish spot. The compound AS3 is still under further identification, thus, cannot be displayed in this paper. The initial identification process was indicating of proton signal of methyl, methylene, methine, methoxy, C-C double bond, and aromatic group. Signal proton of compound AS3 presented in Table 3 and Figure 4.
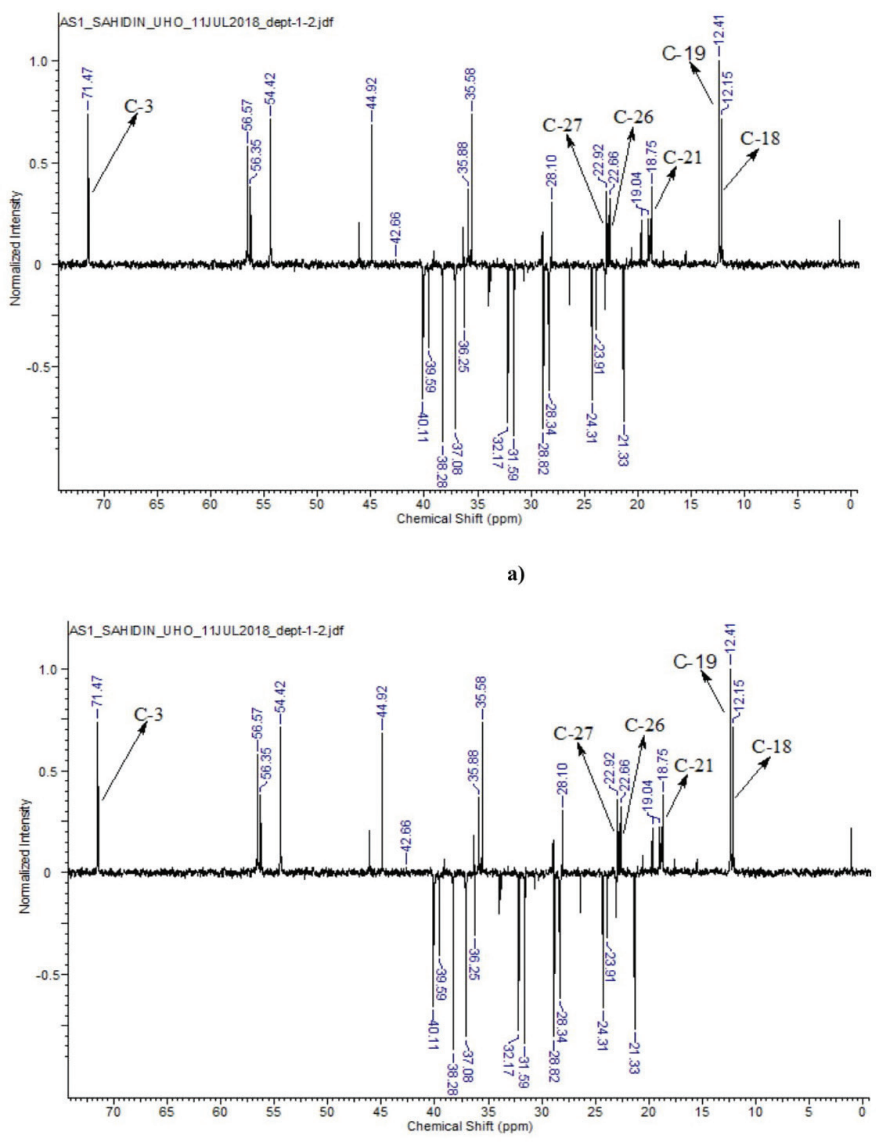

(b)

Figure 1. (a) ${ }^{1} \mathrm{H}$ NMR of compound AS1; (b) ${ }^{13} \mathrm{C}$ NMR of compound AS1. 


\section{Compound AS4}

Compound AS4 was solid reddish oil which fluorescents into orange under light UV $254 \mathrm{~nm}$ and turned out into orange when dissolving with the organic solvent. The signal proton of compound AS4 is cannot be interpreted with ${ }^{1} \mathrm{H}$ NMR thus the structure cannot be determined (Figure 5).

\section{Antioxidant activity}

The antioxidant activity test was carried out on the acetone extract of Aaptos sp. (ASE), AS1, AS2, and AS4 isolates. The test was not conducted on AS3 due to the limited amount of isolate. Qualitatively (Figure 6), showed that ASE,

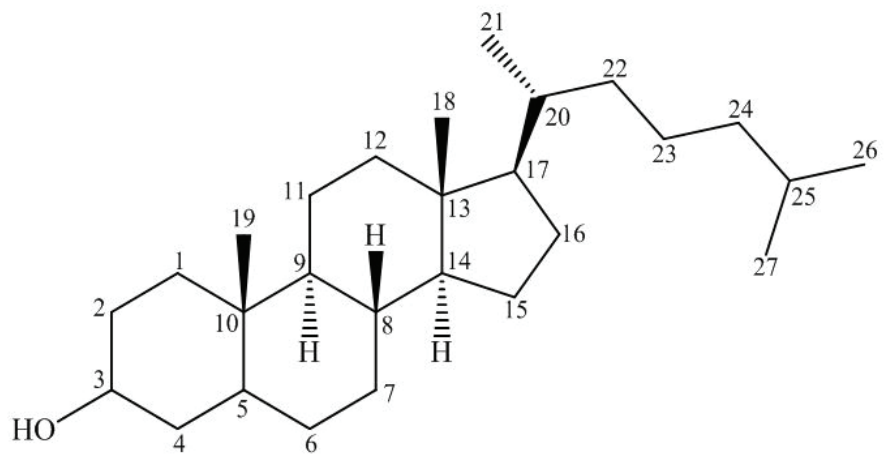

Figure 2. Compund AS1 (cholestanol).
AS2, and AS5 had antioxidant constituent which was visualized on the visible light. The result is characterized by spots with faded yellow on the plate and visualized on UV light with $366 \mathrm{~nm}$ showed spot with light blue although they have low diameter and intensity than ascorbic acid (Badarinath et al., 2010). Discoloration of DPPH occurs due to the effect of the reduction of DPPH radicals compound by mechanism electron donation/hydrogen donation, thus the production of DPPH in non-radical form and reduces the intensity of purplish DPPH color (Molineux, 2004). Visualization under light UV $366 \mathrm{~nm}$ is proving the antioxidant component characterized by the light blue spot on the plate (Gu et al., 2009).

Acetone extract and isolates were measured quantitatively from the antioxidant activity against DPPH free radical (Table 4; Figure 7). acetone extract of Aaptos sp. (ASE) is the only extract that has $\mathrm{IC}_{50}$ value above $50 \%$ namely, $16.10 \mu \mathrm{g} / \mathrm{ml}$. For control, ascorbic acid (AA) provide $\mathrm{IC}_{50}$ values of $23.36 \mu \mathrm{g} / \mathrm{ml}$. The $\mathrm{IC}_{50}$ value of $\mathrm{ASE}$ was lower than the $\mathrm{IC}_{50}$ value of AA possibly due to ASE consisted of a mixture of active compounds and synergically reduces DPPH. Aaptamine is one of predominant compounds that can be found in Aaptos sp. and has acted as an antioxidant (Larghi et al., 2009; Shaari et al., 2009). According to the structure of a compound with one or several $\mathrm{OH}$ molecules can inhibit oxidation and capture reactive free radicals from compounds that can destroy cells. The antioxidant is a reducing agent that is easily oxidized by free radical due to the double bond and $\mathrm{OH}$

Table 2. Signal ${ }^{1} \mathrm{H}$ NMR of compound AS2 (in ppm, measured under $400 \mathrm{MHz}\left({ }^{1} \mathrm{H}\right)$ in $\mathrm{CD}_{3} \mathrm{OD}, \delta \mathrm{TMS}=0$ ).

\begin{tabular}{|c|c|c|}
\hline No. & $\delta_{\mathrm{H}}(\mathrm{m}, \mathbf{J} \mathbf{H z})$ & Estimated functional group \\
\hline $\mathrm{H}-1$ & $0,87(\mathrm{~s})$ & Metal \\
\hline $\mathrm{H}-2$ & $1,26(\mathrm{~s})$ & Metal \\
\hline H-3 & $2,02(\mathrm{~d}, 8)$ & Methylene \\
\hline $\mathrm{H}-4$ & $2,24(\mathrm{t}, 4)$ & Methylene/Methine \\
\hline H-5 & $2,64(\mathrm{~s})$ & Methine \\
\hline H-6 & $3,44(d, 8)$ & Methylene/Methine (bond to electronegative atoms or have $\pi$ bonds) \\
\hline $\mathrm{H}-7$ & $3,62(d, 4)$ & Methylene/Methine (bond to electronegative atoms or have $\pi$ bonds) \\
\hline $\mathrm{H}-8$ & $3,93(\mathrm{~s})$ & Methoxy \\
\hline H-9 & $3,98(d, 8)$ & Methylene/Methine (bond to electronegative atoms or have $\pi$ bonds) \\
\hline $\mathrm{H}-10$ & $4,02(\mathrm{~s})$ & Methoxy \\
\hline $\mathrm{H}-11$ & $4,10(\mathrm{~s})$ & Methoxy \\
\hline $\mathrm{H}-12$ & $4,19(d, 8)$ & Double bond \\
\hline $\mathrm{H}-13$ & $4,23(\mathrm{~s})$ & Double bond \\
\hline $\mathrm{H}-14$ & $4,32(\mathrm{q}, 8)$ & Double bond \\
\hline $\mathrm{H}-15$ & $6,68(s)$ & Double bond/aromatic \\
\hline $\mathrm{H}-16$ & $7,05(\mathrm{~d}, 8)$ & Double bond/aromatic \\
\hline $\mathrm{H}-17$ & $7,14(d, 4)$ & Double bond/aromatic \\
\hline $\mathrm{H}-18$ & $7,19(\mathrm{dd},(8,4))$ & Double bond/aromatic \\
\hline H-19 & $7,43(\mathrm{t}, 4)$ & Double bond/aromatic \\
\hline $\mathrm{H}-20$ & $7,60(\mathrm{t}, 4)$ & Double bond/aromatic \\
\hline $\mathrm{H}-21$ & $7,69(t, 4)$ & Double bond/aromatic \\
\hline $\mathrm{H}-22$ & $8,32(\mathrm{~s})$ & Aromatic \\
\hline
\end{tabular}




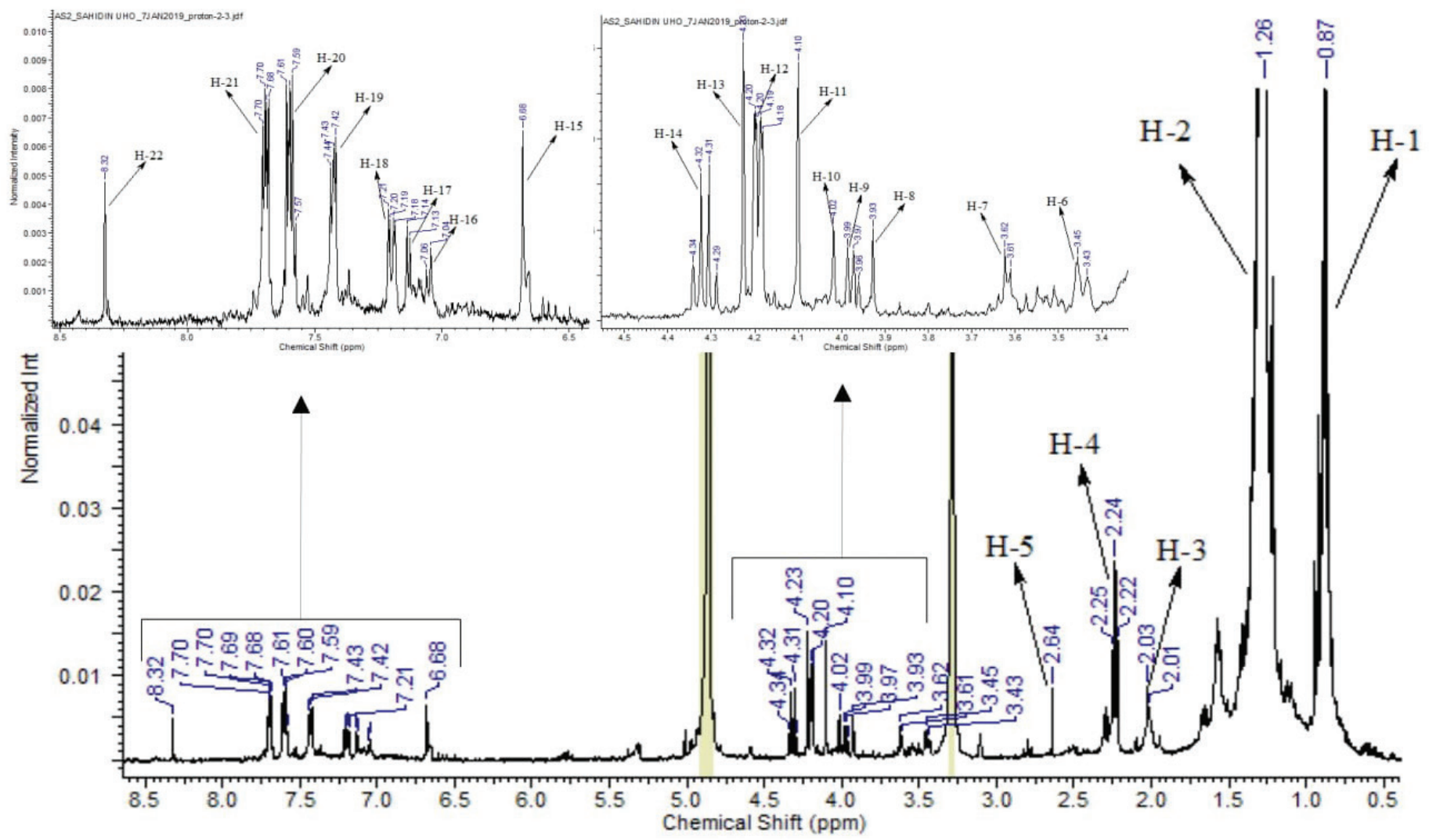

Figure 3. ${ }^{1} \mathrm{H}$ NMR of compound AS2.

Table 3. signal of ${ }^{1} \mathrm{H}$ NMR of compound AS3 (in ppm, measured at $400 \mathrm{MHz}\left({ }^{1} \mathrm{H}\right)$ in $\mathrm{CD}_{3} \mathrm{OD}, \delta \mathrm{TMS}=0$ ).

\begin{tabular}{|c|c|c|}
\hline No. & $\delta_{\mathrm{H}}(\mathrm{m}, \mathrm{J} \mathrm{Hz})$ & Estimated functional group \\
\hline $\mathrm{H}-1$ & $0,87(\mathrm{~s})$ & Metal \\
\hline $\mathrm{H}-2$ & $1,26(\mathrm{~s})$ & Metal \\
\hline $\mathrm{H}-3$ & $1,82(\mathrm{~s})$ & Methylene \\
\hline $\mathrm{H}-4$ & $2,25(\mathrm{t}, 8)$ & Methylene/methinee \\
\hline $\mathrm{H}-5$ & $3,62(\mathrm{~s})$ & Methoxy \\
\hline H-6 & $3,98(\mathrm{~d}, 8)$ & Methylene/Methine (bond to electronegative atoms or have $\pi$ bonds) \\
\hline $\mathrm{H}-7$ & $4,19(\mathrm{~d}, 8)$ & Double bond \\
\hline $\mathrm{H}-8$ & $4,31(\mathrm{q}, 4)$ & Double bond \\
\hline $\mathrm{H}-9$ & $6,59(\mathrm{~d}, 8)$ & Double bond/aromatic \\
\hline $\mathrm{H}-10$ & $6,68(\mathrm{~s})$ & Double bond/aromatic \\
\hline $\mathrm{H}-11$ & $6,83(\mathrm{q}, 4)$ & Double bond/aromatic \\
\hline $\mathrm{H}-12$ & $7,19(\mathrm{~s})$ & Double bond/aromatic \\
\hline $\mathrm{H}-13$ & $7,38(\mathrm{t}, 8)$ & Double bond/aromatic \\
\hline $\mathrm{H}-14$ & $7,43(t, 4)$ & Double bond/aromatic \\
\hline $\mathrm{H}-15$ & $7,59(q, 4)$ & Double bond/aromatic \\
\hline H-16 & $7,69(\mathrm{q}, 4)$ & Double bond/aromatic \\
\hline $\mathrm{H}-17$ & $7,82(\mathrm{~d}, 8)$ & Double bond/aromatic \\
\hline
\end{tabular}

molecular bonds become double bond, thereby the free radicals will accept hydrogen atom resulting in the formation of oxygen radicals. Thereafter, oxygen radical is delocalized by resonance, thus produces more stable radicals (Afrianty et al., 2010).

\section{Acute toxicity}

The $\mathrm{LC}_{50}$ of acetone extract of Aaptos sp. (ASE), compound AS1, compound AS2, compound AS5 were 1041.5, 1488.33, 681.87 , and $783.21 \mu \mathrm{g} / \mathrm{ml}$, respectively (Figure 8). According to 


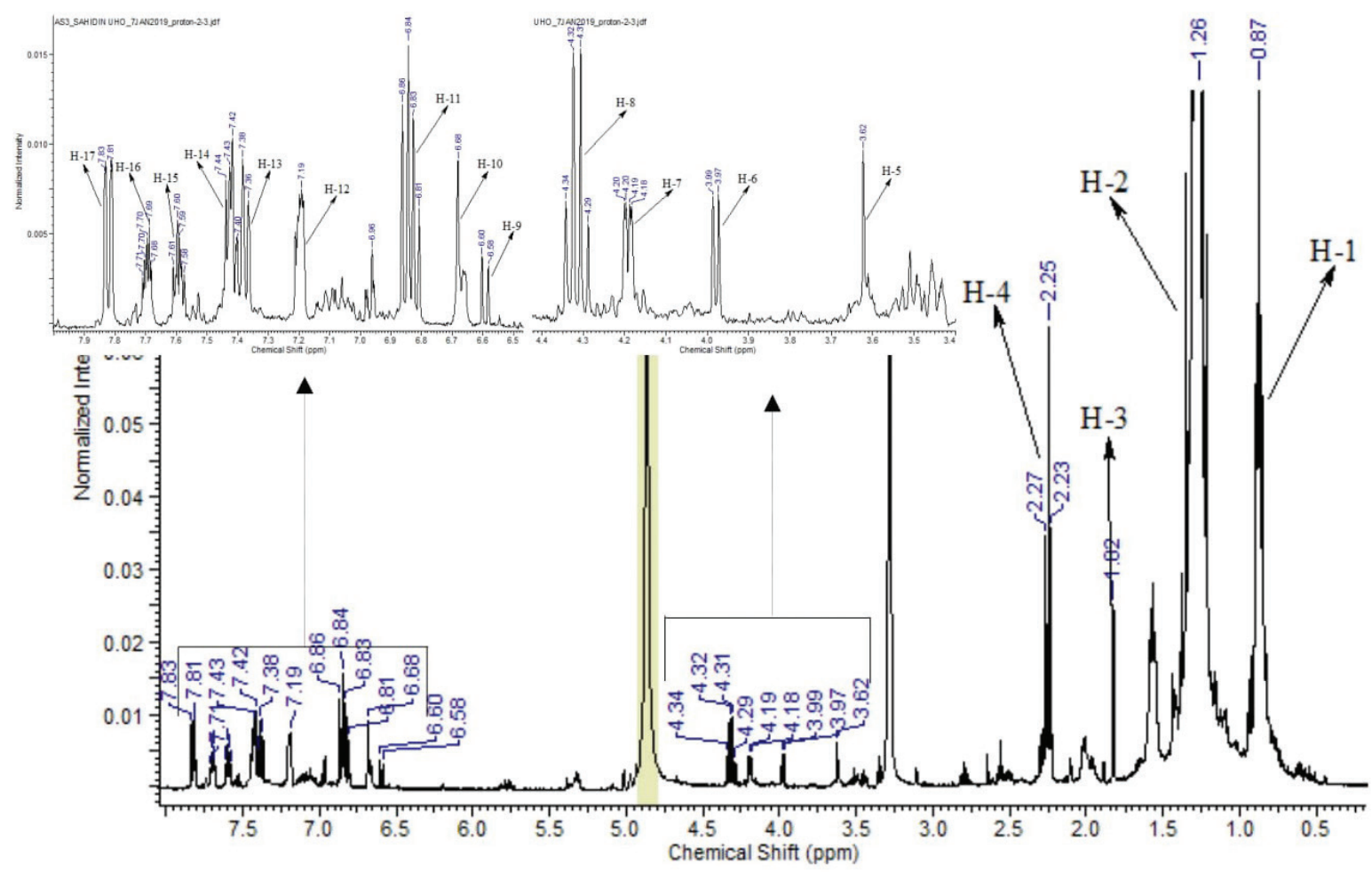

Figure 4. ${ }^{1} \mathrm{H}$ NMR of compound AS3.

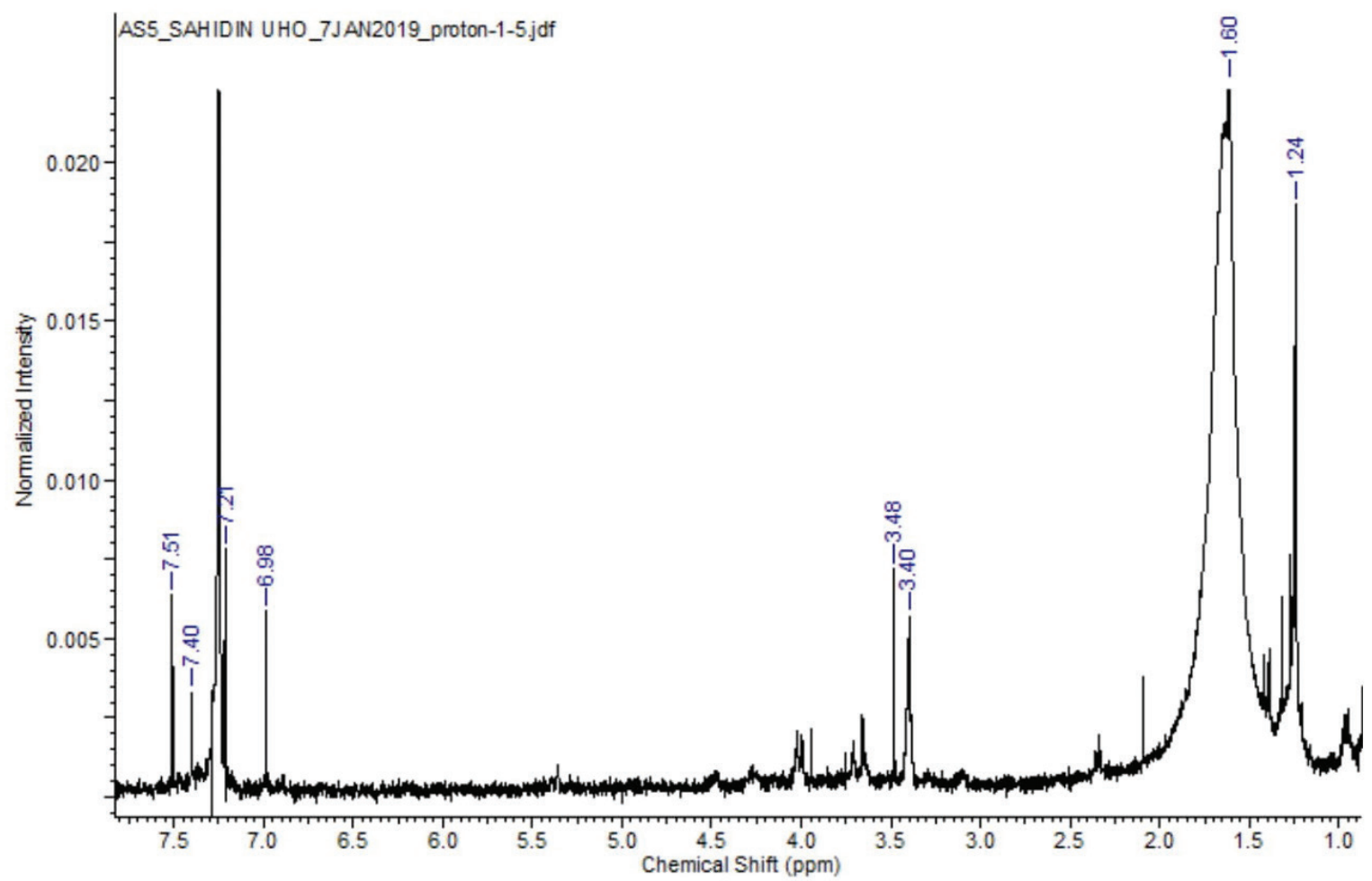

Figure 5. ${ }^{1} \mathrm{H}$ NMR of compound AS4. 


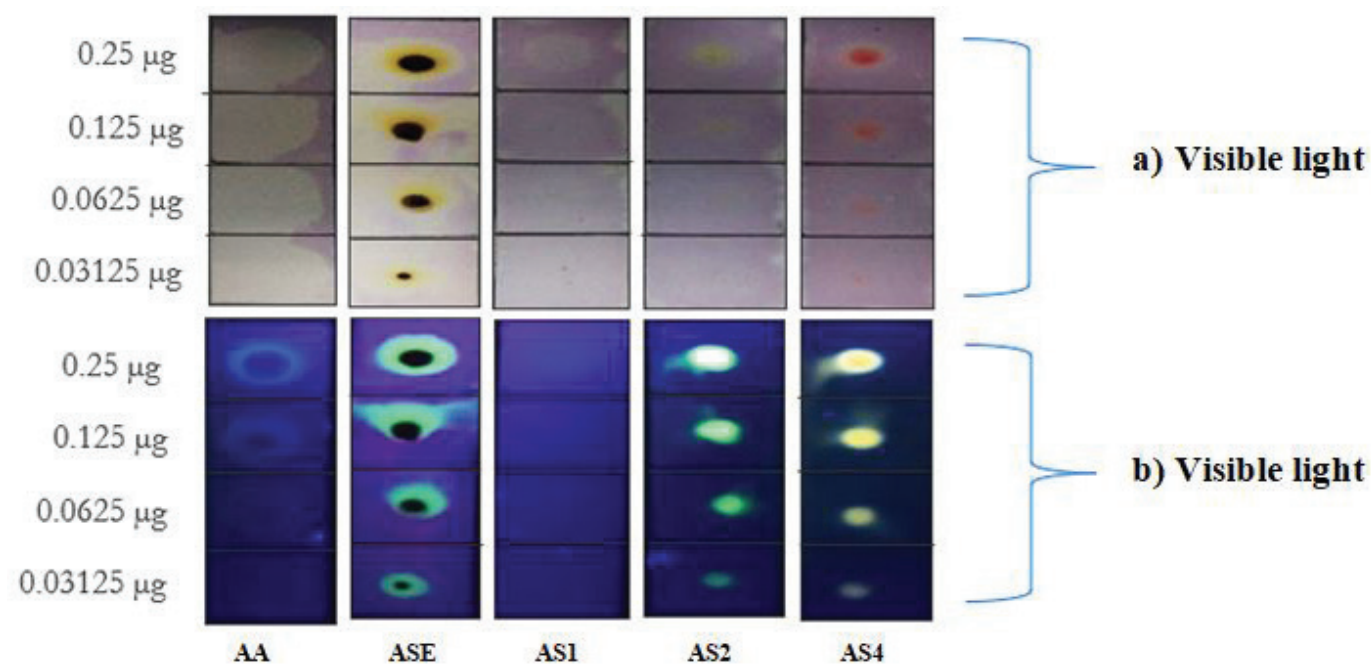

Figure 6. Qualitative test of antioxidant activity (a) Visible light; (b) UV light $366 \mathrm{~nm}$.

Table 4. $\mathrm{IC}_{50}$ values of sample.

\begin{tabular}{|c|c|c|c|}
\hline Sample & Concentration $(\mu \mathrm{g} / \mathrm{mL})$ & \%Inhibition* & $\mathrm{IC}_{50}(\mu \mathrm{g} / \mathrm{ml})$ \\
\hline \multirow{8}{*}{ Ascorbic Acid (AA) } & 200 & $82,46 \pm 0,66$ & \multirow{8}{*}{23,36} \\
\hline & 100 & $82,24 \pm 3,32$ & \\
\hline & 50 & $83,05 \pm 2,40$ & \\
\hline & 25 & $85,30 \pm 2,61$ & \\
\hline & 12,5 & $65,43 \pm 9,15$ & \\
\hline & 6,25 & $26,19 \pm 15,55$ & \\
\hline & 3,125 & $13,24 \pm 11,59$ & \\
\hline & 1,5625 & $15,78 \pm 16,21$ & \\
\hline \multirow{8}{*}{ Acetone ectract of Aaptos sp. (ASE) } & 200 & $60,61 \pm 4,39$ & \multirow{8}{*}{16,10} \\
\hline & 100 & $60,47 \pm 0,18$ & \\
\hline & 50 & $61,43 \pm 0,29$ & \\
\hline & 25 & $44,70 \pm 1,09$ & \\
\hline & 12,5 & $29,15 \pm 2,83$ & \\
\hline & 6,25 & $13,33 \pm 5,15$ & \\
\hline & 3,125 & $10,88 \pm 3,31$ & \\
\hline & 1,5625 & $7,43 \pm 7,07$ & \\
\hline \multirow{8}{*}{ AS1 } & 200 & $16,89 \pm 2,56$ & \multirow{8}{*}{-} \\
\hline & 100 & $19,53 \pm 7,51$ & \\
\hline & 50 & $13,32 \pm 3,41$ & \\
\hline & 25 & $14,67 \pm 5,87$ & \\
\hline & 12,5 & $16,04 \pm 7,19$ & \\
\hline & 6,25 & $14,99 \pm 5,77$ & \\
\hline & 3,125 & $14,03 \pm 5,38$ & \\
\hline & 1,5625 & $13,73 \pm 1,29$ & \\
\hline \multirow{8}{*}{ AS2 } & 200 & $21,55 \pm 6,40$ & \multirow{8}{*}{-} \\
\hline & 100 & $11,87 \pm 0,58$ & \\
\hline & 50 & $12,88 \pm 0,02$ & \\
\hline & 25 & $14,27 \pm 1,96$ & \\
\hline & 12,5 & $14,11 \pm 2,99$ & \\
\hline & 6,25 & $10,42 \pm 4,31$ & \\
\hline & 3,125 & $14,37 \pm 5,69$ & \\
\hline & 1,5625 & $13,05 \pm 2,43$ & \\
\hline
\end{tabular}




\begin{tabular}{lclc}
\hline Sample & Concentration $(\mu \mathrm{g} / \mathrm{mL})$ & \%Inhibition* & IC $_{50}(\mu \mathrm{g} / \mathrm{ml})$ \\
\hline & 200 & $22,08 \pm 1,61$ \\
& 100 & $23,41 \pm 3,94$ \\
& 50 & $16,15 \pm 1,69$ \\
AS4 & 25 & $18,78 \pm 0,24$ \\
& 12,5 & $19,03 \pm 4,01$ \\
& 6,25 & $17,60 \pm 3,49$ \\
& 3,125 & $17,78 \pm 4,01$ \\
\end{tabular}

$*: n+\mathrm{SD}=6$.

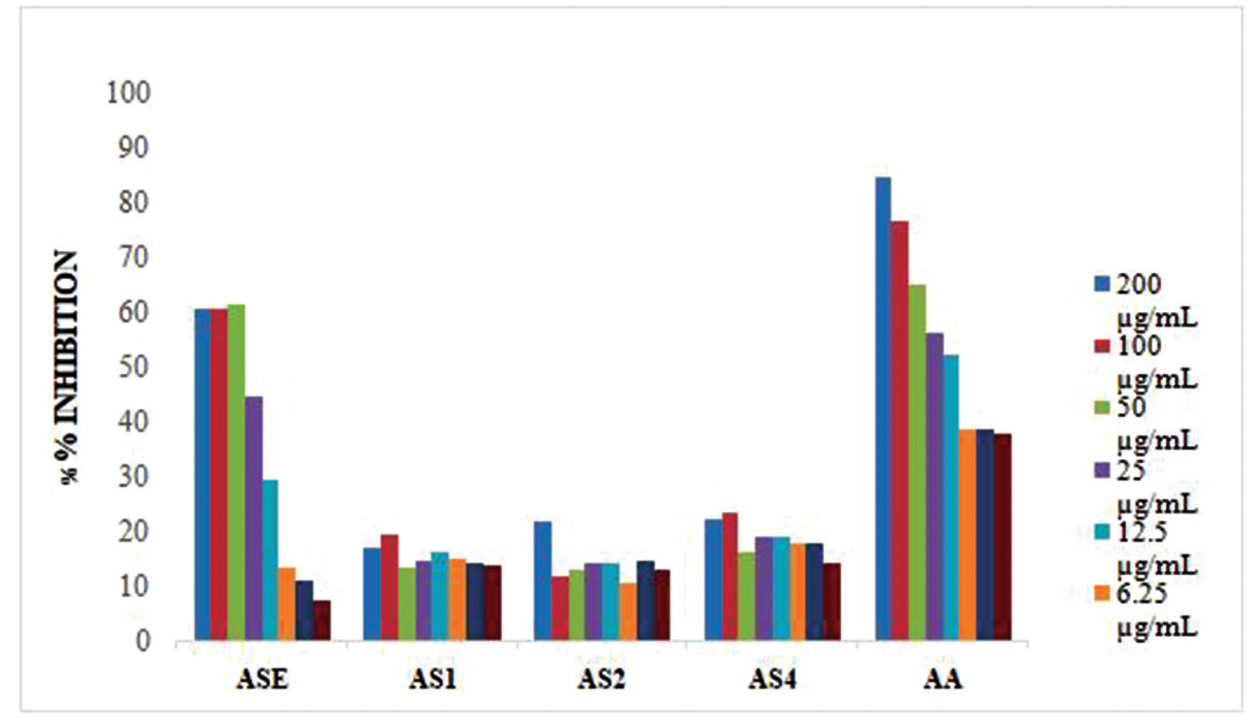

Figure 7. Graphic bar of \%inhibition of extract, isolates, and control (ASE = Acetone extract of Aaptos sp.; AS1 = Compound AS1; AS2 = Compound AS2; AS4 = Compound AS4; A4 = Ascorbic acid).

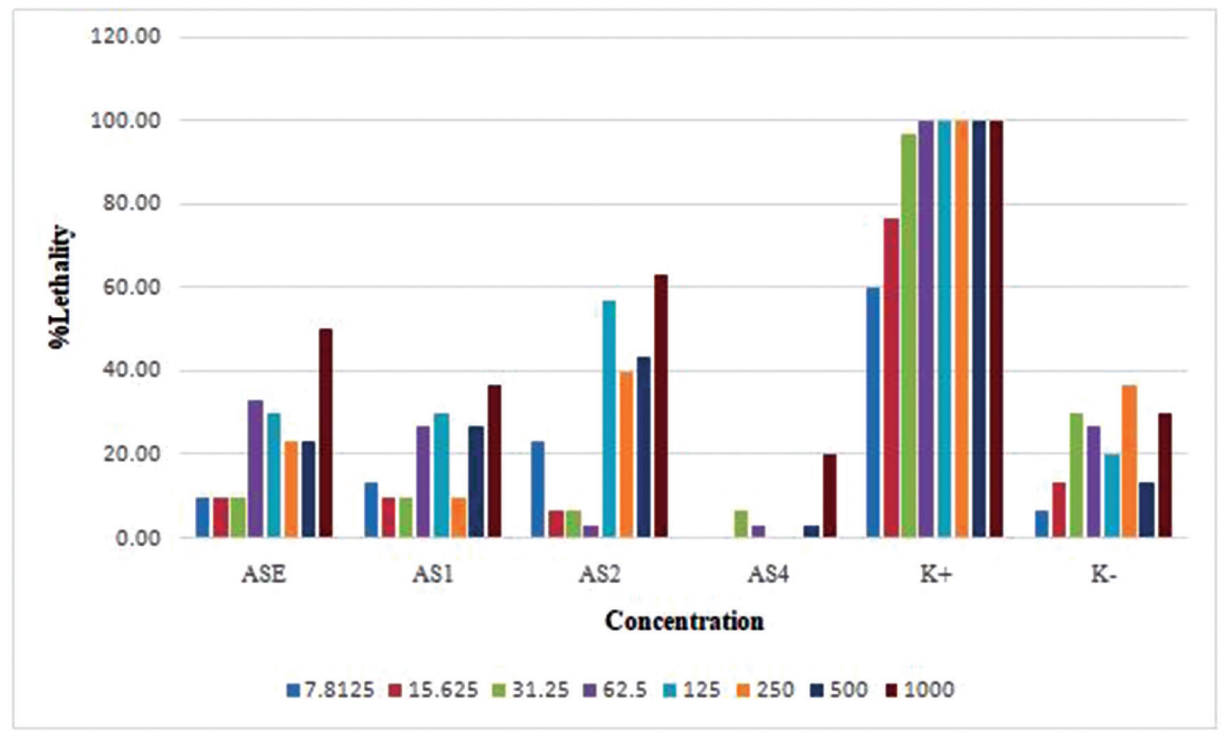

Figure 8. Graphic bar of lethality percentage of A.salina leach (ASE = Acetone extract of Aaptos sp.; AS1 = compound AS1; AS2 = Compound AS2; AS4 = Compound AS4; K+ = potassium dichromate; $\mathrm{K}-=$ DMSO). 
results concluded that $\mathrm{LC}_{50}$ of ASE is not toxic $\left(\mathrm{IC}_{50}>1,000 \mu \mathrm{g} / \mathrm{ml}\right)$ and as well the compound AS1, compound AS2, and compound AS5 are not toxic $\left(\mathrm{LC}_{50}>200 \mu \mathrm{g} / \mathrm{ml}\right)$ (Meyer et al., 1982).

\section{CONCLUSION}

Compounds isolated from acetone extract of Aaptos sp. were four isolates although only cholestanol (AS1) successfully identified. Compound AS2, AS3, and AS4 were not identified yet. Acetone extract of Aaptos sp. has antioxidant activity according to results with $\mathrm{IC}_{50}$ value is $16.10 \mu \mathrm{g} / \mathrm{ml}$ (Ascorbic acid as the positive control, $\mathrm{IC}_{50}$ value is $23.36 \mu \mathrm{g} / \mathrm{ml}$ ). Besides that, the compound AS1, compound AS2, and compound AS5 were not measured due to the percentage of inhibition inadequate to $50 \%$. Acetone extract of Aaptos sp. (ASE), AS1, AS2, and AS5 are not toxic with $\mathrm{LC}_{50}$ values weres 1,041.57, 1,488, 681.87, and 783.21 $\mu \mathrm{g} / \mathrm{ml}$, respectively.Further study needed to investigate secondary metabolites of Aaptos sp. and its activities in many aspects, thus broaden information about a pharmacological aspect of Aaptos sp. in treatment. MS and IR spectrum data are needed for determining the further chemical structure

\section{ACKNOWLEDGMENTS}

The authors would like to thank the Ministry of Research, Technology, and Higher Education of the Republic of Indonesia (KEMENRISTEKDIKTI Republik Indonesia).

\section{CONFLICT OF INTEREST}

The authors declared no conflict of interest.

\section{FUNDING}

This research was supported by the Ministry of Research, Technology, and Higher Education of the Republic of Indonesia by a research grant scheme (Penelitian Dasar Unggulan Perguruan Tinggi 2019) for financial support with grant number 519a/UN29.20/PPM/2019.

\section{AUTHORSHIP}

Study concepts: I.S., A.F., and B.S. Study design: I.S., A.F., W.W., and M.H.M. Data acquisition: A.F., B.S., F.A., W.W., and F.M. Quality control of data and alghoritms: A.F., W.W., F.A., F.M., and L.O.M.J.P. Data analysis and interpretation: I.S., A.F., W.W., and F.A. Manuscript preparation: I.S., A.F., and L.O.M.J.P. Manuscript editing: I.S., A.F., and L.O.M.J.P. All authors reviewed the manuscript.

\section{REFERENCES}

Afrianty LH, Elin YS, Slamet I, Ketut, AI. Studies on 2-Methylester-1-H-Pyrolle-4-Carboxylic acid compound in ethylacetate extract of snake fruit variety bangkok as antioxidant and antihyperuricemic. J Teknol Dan Industri Pangan, 2010; XXI(1):66-72.

Andreanus A, Endang K, Cucu A. Toksisitas Akut dan Penentuan DL50 Oral Ekstrak Air Daun Gandarusa (Justicia gendarussa Burm. F.) pada Mencit Swiss Webster. Jurnal Matematika dan Sains, 2002; 7(2): $57-62$.
Aoki S, Dexin K, Hideaki S, Yoshihiro S, Toshiyuki S, Andi S, Motomasa K. Aaptamine, a spongean alkaloid, activates $\mathrm{p} 21$ promoter in A p53-independent manner. Biochem Bioph Res Co, 2006; 342:101-2.

Badarinath AV, Malikarjuna R, Madhu SC, Ramkanth RTVS, Gnanaprakash K. A review on In-vitro antioxidant methods: comparisions, correlations and considerations. Int J Pharm Tech Res, 2010; 2(2):1276-85.

Dharini M., Salma P, Kothari V. Antioxidant therapy: potential and limitations. IJSMT, 2010; 3(4):25-36.

Gu L, Tao W, Zhengtao W. TLC Bioautography-guided isolation of antioxidants from fruit of perilla frutescens var. Acuta. Food Sci Technol, 2009; 42(1):131-36.

Kabel AM. Free radicals and antioxidants: role of enzymes and nutrition. World J Nutr Health, 2014; 2(3):35-8.

Kudo Y, Hikaru K, Henki R, Fitje L, Remi EPM, Nicole JDV, Sachiko T. Aaptoline a new quinoline alkaloid from the marine sponge Aaptos suberitoides. Heterocycles, 2014; 88(1):417-24.

Larghi EL, Maria LB, Teodoro SK. Aaptamine and related products. Their isolation, chemical syntheses, and biological activity. Tetrahedron, 2009; 65:4257-82.

Lobo V, Patil A, Phatak A, Chandra N. Free radicals, antioxidants, and functional foods: impact on human health. Pharmacon Rev, 2010; 4(8):118-26.

Meyer BN, Ferrigni NR, Putnam JE, Jacobsen LB, Nichols DE, McLaughlin JL. Brine shrimp: a convenient general bioassay for active plant constituents. J Med Plant Res, 1082; 45:31-34.

Mohamad H, Zalilawati MR, Khozirah S, Jalifah L, Md NHJ, Abdul M. Antibacterial and DPPH free radical-scavenging activities of methanolic extract of Aaptos sp., (Marine Sponges). Pertanika J Trop Agric Sci, 2009; 32(1):44.

Molineux P. The use of the stable free radical diphenyl picrylhydrazil (DPPH) for estimating antioxidant activity. Songklankarin J SciTechnol, 2004; 26(2):211-9.

Pavia DL, Lampman GM, Kriz GS, Vyvyan JR. Introduction to spectroscopy. Cengage Learning, Stamford, USA, Quiao MAD, Myelene MU. Pyrimidines from the Philippine Marine Sponge Aaptos suberitoides. Int J Sci Eng Res, 2013; 4:1-4.

Shaari K, Kee CL, Zalilawati MR, Tan PJ, Farida A, Salahudin MR, Zurina Z, Nordin HL, Habsah M, Abdul MA. Cytotoxic aaptamines from Malaysian Aaptos aaptos. Mar Drugs, 2009; 7: 1-8.

Tsukamoto S, Rumi Y, Makiko Y, Kohei S, Tsuyoshi I, Henki R, Remy EPM, Nicole JDV, Rob WMVS, Hideyoshi Y. Aaptamine, an alkaloid from the Sponge Aaptos suberitoides, functions as a proteasome inhibitor Bioorg Med Chem Lett, 2010; 20:3341.

Uli H, Alfian N, Mandey FW, Ajuk S. Isolation, identification and bioactivity test of non-polar compounds on n-hexane extract of haliclona (reniera) fascigera from Samalona Island-spermonde archipelago. Int J Marina Chim Acta, 2017; 17(2):32-42.

Wojick M, Burzynska P, Wozniak LA. A review of natural and synthetic antioxidants important for health and longevity. Cur Med Chem, $2010 ; 17(28): 3262-88$

How to cite this article:

Fristiohady A, Sadarun B, Wahyuni W, Malaka MH, Ahmad F, Malik F, Purnama LOMJ, Sahidin I. Isolation and identification of secondary metabolite acetone extract Aaptos sp. and its antioxidant properties and acute toxicity. J Appl Pharm Sci, 2020; 10(06):081-089. 